\title{
Ascorbic acid accumulation and transport in human fibroblasts
}

\author{
Richard W. WELCH, ${ }^{\star}$ Peter BERGSTEN, ${ }^{\star}$ Jean DeB. BUTLER $\dagger$ and Mark LEVINE $\ddagger$ \\ *Laboratory of Cell Biology and Genetics, National Institute of Diabetes, Digestive, and Kidney Diseases, \\ and HHuman Genetics Branch, National Institute of Child Health and Human Development, National Institutes of Health, Bethesda, MD 20892, U.S.A.
}

\begin{abstract}
As the initial step in the use of fibroblasts as a model system for 'in situ kinetics', ascorbic acid (vitamin C) accumulation in normal human fibroblasts was investigated for the first time. Ascorbic acid was transported into fibroblasts and accumulated against a concentration gradient up to 20 -fold, as measured by h.p.l.c. with coulometric electrochemical detection. Ascorbic acid accumulation was mediated by two concentration-dependent transport activities. The first was a high-affinity activity with an apparent $K_{\mathrm{m}}$ of $6 \mu \mathrm{M}$ and an apparent $V_{\max }$ of $203 \mu \mathrm{M} / \mathrm{h}$, and the second was a low-affinity activity with an apparent $K_{\mathrm{m}}$ of
\end{abstract}

$5 \mathrm{mM}$ and an apparent $V_{\max }$ of $1.8 \mathrm{mM} / \mathrm{h}$. Both activities were inhibited by metabolic inhibitors and inhibitors of ascorbic acid transport in human neutrophils. The low-affinity transporter could not be accounted for by diffusion. Although the highaffinity transport activity was comparable with that described for human neutrophils, the low-affinity transporter was different. These data provide the first evidence that two-component ascorbic acid transport may be a generalized mechanism for accumulation of this vitamin in humans.

\section{INTRODUCTION}

Ascorbic acid (vitamin C) is essential for normal collagen formation [1,2]. The isolated enzymes procollagenproline,2-oxoglutarate 4-dioxygenase (proline hydroxylase, EC 1.14.11.2), procollagen-proline,2-oxoglutarate 3-dioxygenase (EC 1.14.11.7), and procollagen-lysine,2-oxoglutarate 5-dioxygenase (lysine hydroxylase, EC 1.14.11.4) require ascorbic acid for maximum activity [3-7]. However, enzyme activity in intact tissue as a function of intracellular ascorbic acid concentration is unknown. This issue deserves attention for two reasons. First, collagen biosynthesis is indispensable for wound healing [8]. Surprisingly, the amount of ascorbic acid needed to regulate wound healing in humans is unknown. This knowledge could have important consequences for humans undergoing surgery or with traumatic injuries. Second, the relationship between enzyme activity and ascorbic acid concentration could provide new insight to vitamin requirements [9]. We proposed that ascorbic acid requirements could be determined by applying the principles of apparent enzyme kinetics to ascorbic acid-dependent systems in situ [9]. This approach, termed 'in situ kinetics', has been characterized by this laboratory and represents the first quantitative approach to vitamin requirements [9-15]. Ascorbic acid regulation of collagen biosynthesis in normal human fibroblasts is an ideal application of the principles of in situ kinetics.

An initial step in understanding the relationship between ascorbic acid concentration, enzyme activity and collagen biosynthesis in situ is to investigate intracellular ascorbic acid mass in fibroblasts. However, ascorbic acid mass accumulation within human fibroblasts as a function of external concentration is unknown. The studies in this paper were undertaken to solve this problem, by using an assay for ascorbic acid accumulation developed in this laboratory [16].

\section{MATERIALS AND METHODS}

\section{Reagents}

$\left[{ }^{14} \mathrm{C}\right]$ Ascorbic acid, ${ }^{3} \mathrm{H}_{2} \mathrm{O}$ and $\left[{ }^{14} \mathrm{C}\right]$ poly(ethylene glycol) were purchased from DuPont-NEN (Boston, MA, U.S.A.). Ascorbic acid and EDTA were obtained from Sigma (St. Louis, MO, U.S.A.), and methanol was purchased from Baker (Philipsburg, NJ, U.S.A.). Other reagents were of the highest commercial grade.

\section{Fibroblast culture}

Skin fibroblasts identified as 5757, 3349, 5659, 1489 and 4390 were obtained from the Human Genetics Mutant Cell Repository (Camden, NJ, U.S.A.). One culture line, identified as RS, was obtained from a biopsy of a patient with informed consent. Fibroblasts were cultured in Eagle's minimal essential medium with extra non-essential amino acids, $2 \mathrm{mM}$ glutamine and $10 \%$ heat-inactivated fetal-bovine serum (GIBCO, Grand Island, NY, U.S.A.). Cells were cultured at $37^{\circ} \mathrm{C}$ in a $5 \%-\mathrm{CO}_{2}$ humidified atmosphere. Cells were split with $0.05 \%$ trypsin $/ 0.53 \mathrm{mM}$ EDTA.

\section{Determination of intracellular volume of fibroblasts}

Intracellular volume was measured by using ${ }^{3} \mathrm{H}_{2} \mathrm{O}$ and $\left[{ }^{14} \mathrm{C}\right]$ poly(ethylene glycol) $[14,15]$ and monitored by electronic cell counting (Coulter, Hialeh, FL, U.S.A.). Experiments were performed on 6-well tissue-culture plates. Protein was determined from the same cells, and an average value of intracellular volume $/ \mu \mathrm{g}$ of protein was obtained.

\section{Transport and accumulation of ascorblc acid}

Fibroblasts were plated at half-confluency in 12-well tissue culture dishes and grown until just confluent. For experiments, culture medium was removed; cells were rinsed and incubated for $15 \mathrm{~min}$ in $2 \mathrm{ml}$ of Balanced Salt Solution (BSS) containing $150 \mathrm{mM} \mathrm{NaCl}, 5 \mathrm{mM} \mathrm{KCl}, 1.9 \mathrm{mM} \mathrm{KH}_{2} \mathrm{PO}_{4}, 1.1 \mathrm{mM} \mathrm{Na}_{2} \mathrm{HPO}_{4}$, $5.5 \mathrm{mM}$ glucose, $0.3 \mathrm{mM} \mathrm{MgSO}_{4}, 7 \mathrm{H}_{2} \mathrm{O}, 1 \mathrm{mM} \mathrm{MgCl}_{2}, 6 \mathrm{H}_{2} \mathrm{O}$, $1.5 \mathrm{mM} \mathrm{CaCl} 2,2 \mathrm{H}_{2} \mathrm{O}$ and $10 \mathrm{mM}$ Hepes, adjusted to $\mathrm{pH} 7.4$ with $\mathrm{NaOH}$. The BSS was removed and $0.5 \mathrm{ml}$ of fresh BSS was added with the indicated concentrations of $\left[{ }^{14} \mathrm{C}\right]$ ascorbic acid or ascorbic acid; cells were incubated as specified. The metabolic inhibitors carbonyl cyanide 4-trifluoromethoxyphenylhydrazone

Abbreviations used: FCCP, carbonyl cyanide 4-trifluoromethoxyphenylhydrazone; DNP, 2,4-dinitrophenol; BSS, balanced salt solution

¥ To whom correspondence should be addressed, at: Building 8, Room 415, National Institutes of Health, Bethesda, MD 20892, U.S.A 
(FCCP), 2,4-dinitrophenol (DNP), phloretin, cytochalasin B and phlorizin were dissolved in ethanol; $\mathrm{KCN}$ was dissolved in $\mathrm{Na}^{+}$-free BSS. Inhibitors were added to cells for a $15 \mathrm{~min}$ preincubation, after which ascorbic acid at the indicated concentration was added to the cultures and incubated for $4 \mathrm{~h} . \mathrm{Na}^{+}$free BSS contained $\mathrm{K}_{2} \mathrm{HPO}_{4}$ and choline chloride in place of $\mathrm{Na}_{2} \mathrm{HPO}_{4}$ and $\mathrm{NaCl}$ at appropriate concentrations to maintain ionic strength. Cells were incubated in a $5 \%-\mathrm{CO}_{2}$ humidified atmosphere at $37^{\circ} \mathrm{C}$ unless otherwise indicated. After incubation, culture dishes were placed on ice; $250 \mu \mathrm{l}$ of medium was removed, added to $500 \mu \mathrm{l}$ of $90 \%$ methanol saturated with EDTA, and frozen on solid $\mathrm{CO}_{2}$ immediately. Cells were then washed with $2 \times 2 \mathrm{ml}$ of ice-cold BSS. Intracellular ascorbic acid was extracted with $0.5 \mathrm{ml}$ of ice-cold $60 \%$ methanol/1 mM EDTA. The methanol/EDTA was gently swirled in the culture wells for $2 \mathrm{~min}$, then removed and immediately frozen on solid $\mathrm{CO}_{2}$. All ascorbic acid samples were stored at $-70^{\circ} \mathrm{C}$ for analysis, and cell monolayers were frozen at $-20^{\circ} \mathrm{C}$ for protein determination.

\section{Assays}

Ascorbic acid extracts were analysed for both mass and radioactivity. Mass was analysed by h.p.l.c. with coulometric electrochemical detection [16]. Purity of the intracellular label was determined by collecting fractions from h.p.l.c. analysis by using a fraction collector with minimal dead volume (LKBPharmacia); radioactivity in each fraction was determined by scintillation spectrometry (Beckman LS-5801). Purity of radiolabel was also determined by comparison of $\mathrm{Bq}$ and specific radioactivity of radiolabelled medium with h.p.l.c. analysis of the same medium. Cell protein was determined by the BCA method [17] after solubilization of cell monolayers with $1.0 \mathrm{ml}$ of $1 \%$ CHAPS/0.1 M NaOH.

Results were calculated as pmol of ascorbate $/ \mu \mathrm{g}$ of cellular protein, and when indicated were converted into $\mathrm{mM}$ amounts. Experimental points represent the mean \pm S.D. of at least three samples. Error bars were omitted when the S.D. was less than the size of the symbol. Linear-regression analysis was performed with the kinetic software package ENZFITTER.

\section{Extracellular ascorbic acid}

For these kinetic data to be valid, external ascorbic acid concentrations should not change during the incubations. We measured a range of external ascorbic acid concentrations at zero time and after $60 \mathrm{~min}$ incubations with fibroblasts. Ascorbic acid was stable for $60 \mathrm{~min}$ under the conditions used. Ascorbic acid decreased by $10 \%$ every $2 \mathrm{~h}$, in agreement with previous findings [18]. In addition, there was $\leqslant 10 \%$ oxidation of $3.0 \mathrm{mM}$ external ascorbic acid over $18 \mathrm{~h}$ (results not shown).

\section{RESULTS}

Intracellular volume of fibroblasts was $11.0 \pm 2.0 \mu 1 / \mathrm{mg}$ of protein $(n=24)$. By using these data, intracellular ascorbic acid measured as $\mathrm{pmol} / \mu \mathrm{g}$ of protein was expressed as an intracellular concentration when indicated. The uptake of ascorbic acid was linear for several hours, as determined by both scintillation spectrometry and electrochemical detection (Figure 1). As results from scintillation spectrometry for uptake of $\left[{ }^{14} \mathrm{C}\right]$ ascorbic acid were consistent with transport results obtained from electrochemical detection of total ascorbic acid mass, only mass data are shown unless otherwise noted.

\section{High-affinity ascorblc acld transport}

As ascorbic acid uptake was linear for several hours, $1 \mathrm{~h}$ time points were chosen for kinetic analyses. Fibroblasts were incubated with 1.25-500 $\mu \mathrm{M}$ ascorbic acid; uptake was determined by h.p.l.c. Ascorbic acid uptake occurred as two activities, as evident in both the substrate/velocity curve (Figure 2a) and Eadie-Hofstee analyses (inset to Figure 2a). To separate the two activities, we subtracted the linear portions of the substrate-versus-velocity curves (extracellular ascorbic acid concentrations $\geqslant 100 \mu \mathrm{M}$ ) [19]. Lines were constructed from these data points by regression analysis, extrapolated through the ordinate, and recalculated with an ordinate intercept of 0 $(r=0.99)$. The values determined from these lines were subtracted from the observed uptake at the appropriate substrate concentrations, and the results were replotted (Figure 2b). Ascorbic acid accumulation measured by h.p.l.c. was mediated by a transport activity with an apparent $K_{\mathrm{m}}$ of $8 \mu \mathrm{M}$ and an apparent $V_{\max }$ of $260 \mu \mathrm{M} / \mathrm{h}$ by Eadie-Hofstee and Lineweaver-Burk analyses (Figure 2b). Ascorbic acid accumulation from this transporter was saturable and concentrationdependent. For descriptive purposes we refer to this activity as the high-affinity transport activity. Constants from three different cell lines (RS, 4390, 1489) were determined by using Eadie-Hofstee and Lineweaver-Burk analyses: the average apparent $K_{\mathrm{m}}$ of the high-affinity activity was $6 \pm 2 \mu \mathrm{M}$, and the average apparent $V_{\max }$ was $203 \pm 50 \mu \mathrm{M} / \mathrm{h}$. These values were similar to the apparent $K_{\mathrm{m}}$ and apparent $V_{\max }$. calculated by using a non-linear regression program, with data from five different cell lines.

\section{Low-affinity ascorbic acid transport}

It was necessary to account for the non-saturating linear component of ascorbic acid transport (Figure 2a). This activity was distinct from the high-affinity transport activity, as seen in the Eadie-Hofstee analyses (inset in Figure 2a). To describe this second transport activity, human fibroblasts were incubated with 1-10 $\mathrm{mM}$ ascorbic acid for $2 \mathrm{~h}$, during which time uptake was linear. Attempts to increase the extracellular ascorbic acid concentrations above $10 \mathrm{mM}$ resulted in toxicity and cell

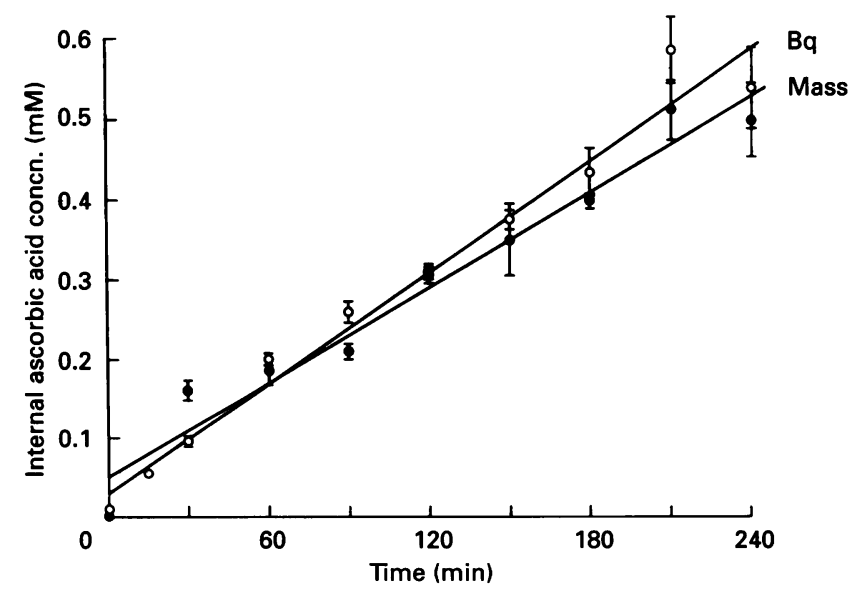

Figure 1 Ascorbic acid accumulation in human fibroblasts as a function of time

Fibroblasts were incubated with $50 \mu \mathrm{M}$ external $\left[{ }^{14} \mathrm{C}\right]$ ascorbic acid for as long as $4 \mathrm{~h}$. Uptake was determined by h.p.I.c. with electrochemical detection (O) or scintillation spectrometry (O). 

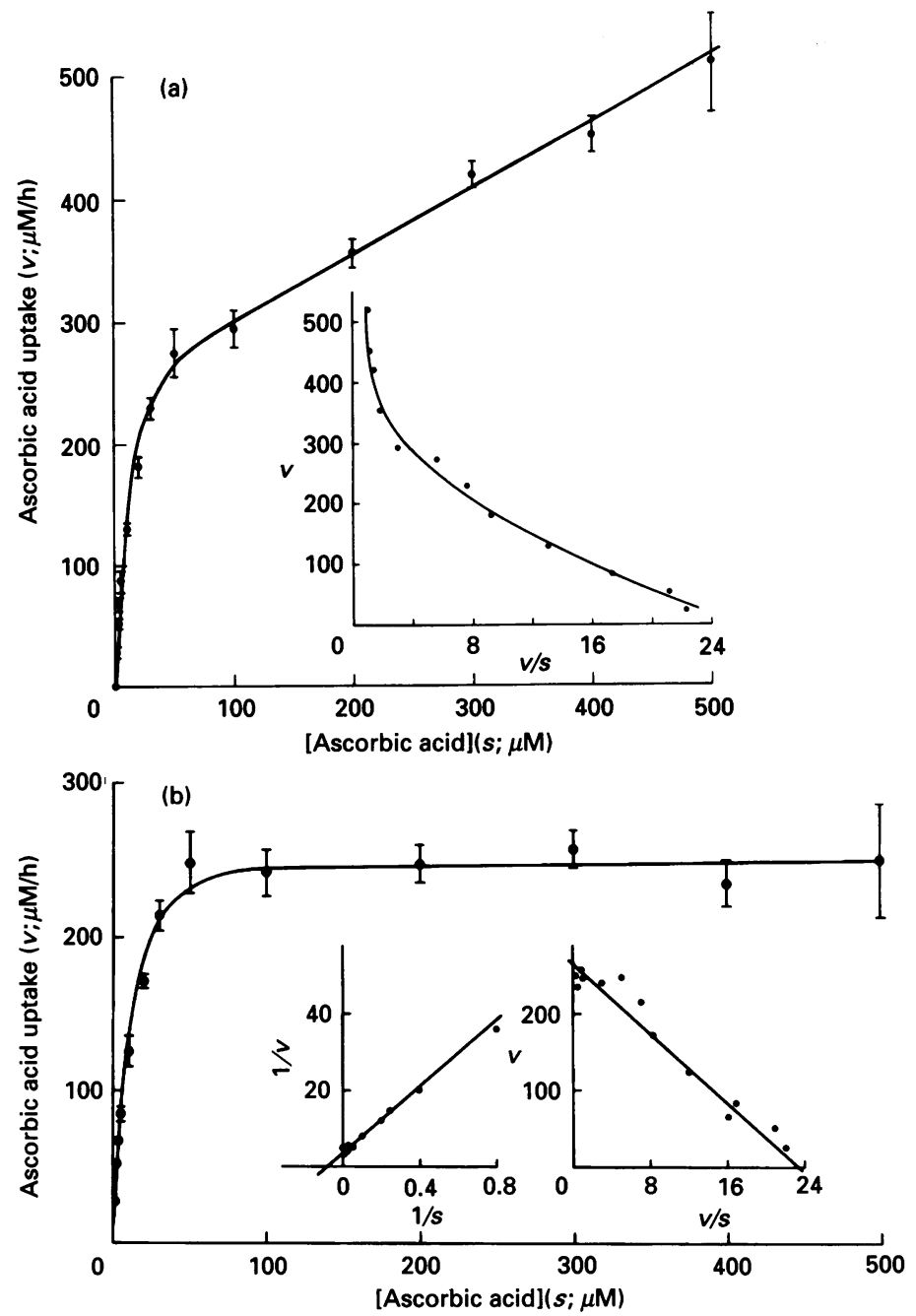

Figure 2 Concentration-dependence of ascorbic acid uptake in human fibroblasts

Fibroblasts were incubated for $1 \mathrm{~h}$ with 1.25-500 $\mu \mathrm{M}$ ascorbic acid. Assays were performed as described in the Materials and methods section. (a) Ascorbic acid uptake measured by h.p.l.c., as a function of external concentration (inset: Eadie-Hofstee analysis). (b) Substrate/velocity curve for mass accumulation of ascorbic acid by the high-affinity transport activity (insets: Lineweaver-Burk analysis, left; Eadie-Hofstee analysis, right). See the text for details.

death. Under these conditions ascorbic acid transport was concentration-dependent but non-saturating, with an apparent $K_{\mathrm{m}}$ of $5 \mathrm{mM}$ and an apparent $V_{\max }$ of $1.8 \mathrm{mM} / \mathrm{h}$ (Figure 3 ). However, the data in Figure 3 did not exclude passive diffusion as a mechanism for the low-affinity activity. To try to distinguish between carrier-mediated transport and passive diffusion, we studied transport in five different cell lines (Figure 4). Although these data provided further evidence of two-component transport, they did not allow determination of the mechanism of the non-saturable activity. An apparent diffusion constant of $0.123 \mathrm{~h}^{-1}$ was calculated from the data in Figure 4.

Previous work had indicated that ascorbic acid transport was $\mathrm{Na}^{+}$-dependent [20,21]. To investigate this possibility, we measured ascorbic acid uptake over a wide range of external ascorbic acid concentrations in the absence or presence of $\mathrm{Na}^{+}$. The high-affinity transporter was $\mathrm{Na}^{+}$-dependent, but the lowaffinity uptake activity was $\mathrm{Na}^{+}$-independent (Figure 5).

Ascorbic acid accumulation against a concentration gradient would distinguish a low-affinity transport activity from diffusion. We therefore incubated fibroblasts for $24 \mathrm{~h}$ in the absence and presence of $\mathrm{Na}^{+}$at external ascorbic acid concentrations of 500 and $1000 \mu \mathrm{M}$. Uptake in the presence of $\mathrm{Na}^{+}$could be attributed to the actions of both the high- and low-affinity transporter activities, whereas uptake in the absence of $\mathrm{Na}^{+}$would be attributed to the low-affinity transport activity alone. As shown in Figure 6, intracellular ascorbic acid concentrations in fibroblasts incubated without $\mathrm{Na}^{+}$were $0.75 \pm 0.06 \mathrm{mM}$ and $1.35 \pm 0.02 \mathrm{mM}$ for external concentrations of $0.5 \mathrm{mM}$ and $1.0 \mathrm{mM}$ respectively. This indicates the presence of a low-affinity transport activity. Subtracting transport in the absence of $\mathrm{Na}^{+}$ from that in its presence yields transport which is strictly $\mathrm{Na}^{+}-$ dependent. The data in Figure 6 calculated in this manner indicate that transport of 500 and $1000 \mu \mathrm{M}$ ascorbic acid was approx. $60-70 \% \mathrm{Na}^{+}$-dependent, as calculated during linear uptake of the vitamin.

If low-affinity ascorbic acid transport activity was mediated by either passive or facilitated diffusion, ascorbic acid should diffuse out of cells as well as into cells. To test further whether lowaffinity activity data could be accounted for by either passive or facilitated diffusion, cells were preincubated in the presence of external ascorbic acid for $2 \mathrm{~h}$, followed by incubation without external ascorbic acid for the same period of time. If diffusion 


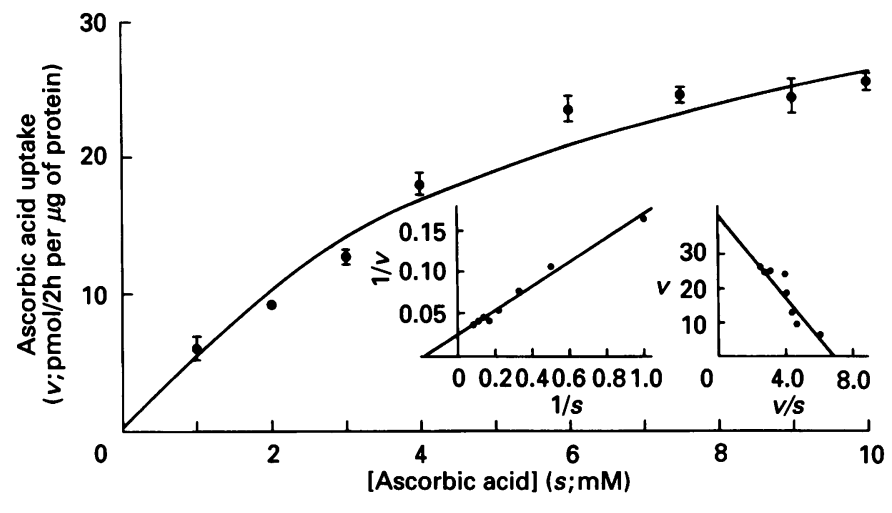

Figure 3 Ascorbic acid uptake as a function of external ascorbic acid (low-affinity transporter)

Fibroblasts were incubated for $2 \mathrm{~h}$ at the indicated ascorbic acid concentrations (insets: Lineweaver-Burk analysis, left; Eadie-Hofstee analysis, right). Ascorbic acid transport by the high-affinity transport activity was subtracted from each data point. Data were fitted to apparent Michaelis-Menten kinetics by using a non-linear regression program. Assays were performed as described in the Materials and methods section.

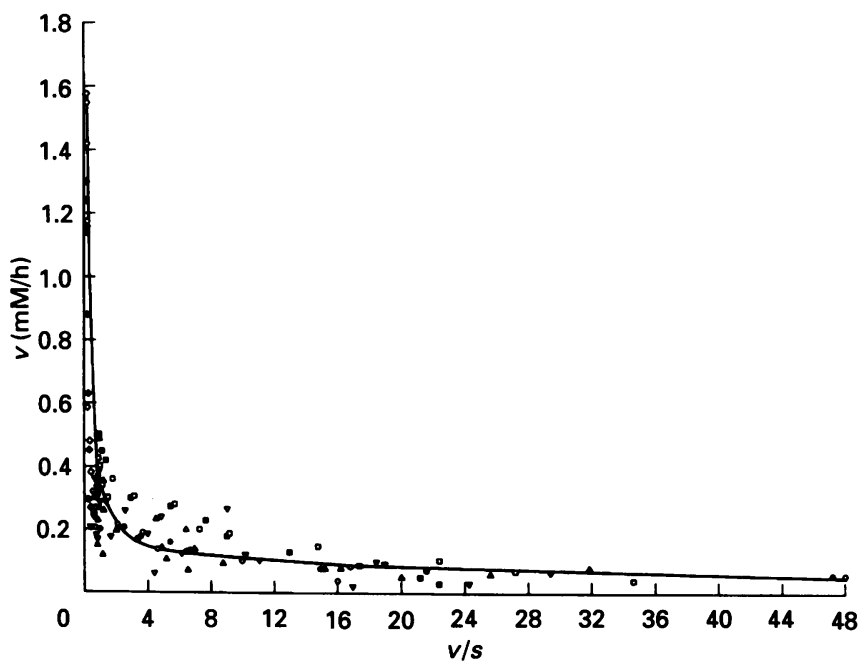

Figure 4 Eadie-Hotstee analysis of ascorbic acid transport in human fibroblasts

Data from five different cell lines, each represented by a different symbol, are shown. Data are plotted in the Eadie-Hofstee format, and the curve drawn in the figure represents the theoretical fit to the primary data using the derived equation. Ascorbic acid accumulation (v) was determined by h.p.l.c. with coulometric electrochemical detection (white symbols) or scintillation spectrometry (black symbols); $s$ is in units of $\mathrm{mM}$.

were the mechanism, intracellular ascorbic acid should have diffused out of the cells when external ascorbic acid was removed. During incubation without ascorbic acid, cells were incubated without $\mathrm{Na}^{+}$to preveni re-accumulation by the high-affinity transport activity. Ascorbic acid was measured both in cells and in medium. As shown in Table 1, the intracellular ascorbic acid concentration remained stable. If ascorbic acid entry via the lowaffinity activity was mediated by passive diffusion, given the $K_{\mathrm{d}}$ of $0.123 \mathrm{~h}^{-1}$ calculated from Figure 4, the internal ascorbic acid should have diffused outwards when external vitamin was removed. The lack of outward diffusion is further evidence that diffusion is not a major component of transport in human

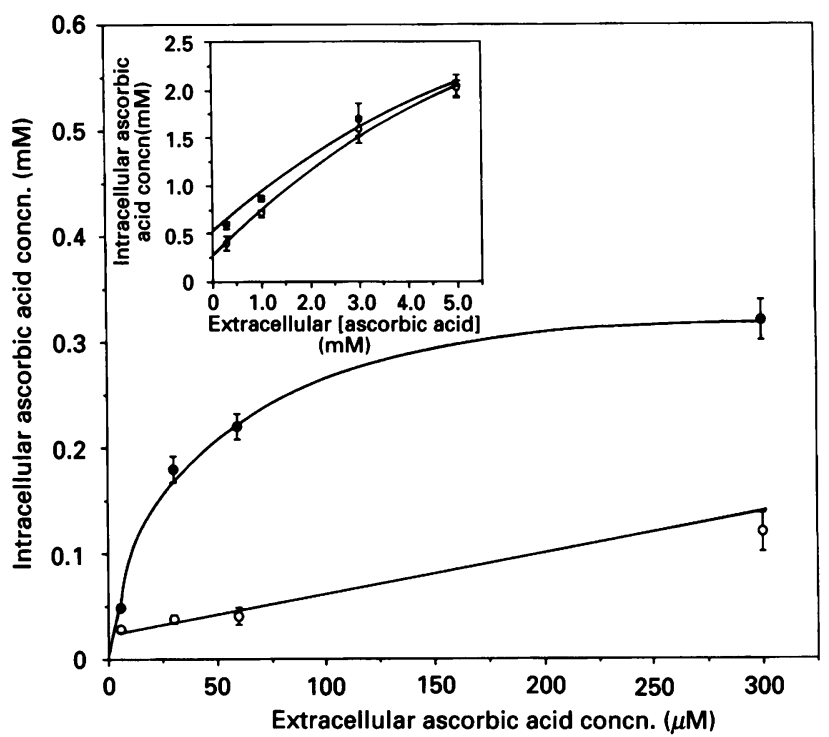

Figure $5 \mathrm{Na}^{+}$-dependence of high-affinity transporter

Fibroblasts were incubated with 6-300 $\mu \mathrm{M}$ ascorbic acid for $2 \mathrm{~h}$. BSS contained either $150 \mathrm{mM} \mathrm{NaCl}(O)$ or $150 \mathrm{mM}$ choline chloride (O). Inset: incubation with $0.3-10 \mathrm{mM}$ ascorbic acid for $2 \mathrm{~h}$. BSS contained either $150 \mathrm{mM} \mathrm{NaCl}(O)$ or $150 \mathrm{mM}$ choline chloride (O). Samples were obtained and analysed as described in he Materials and methods section.

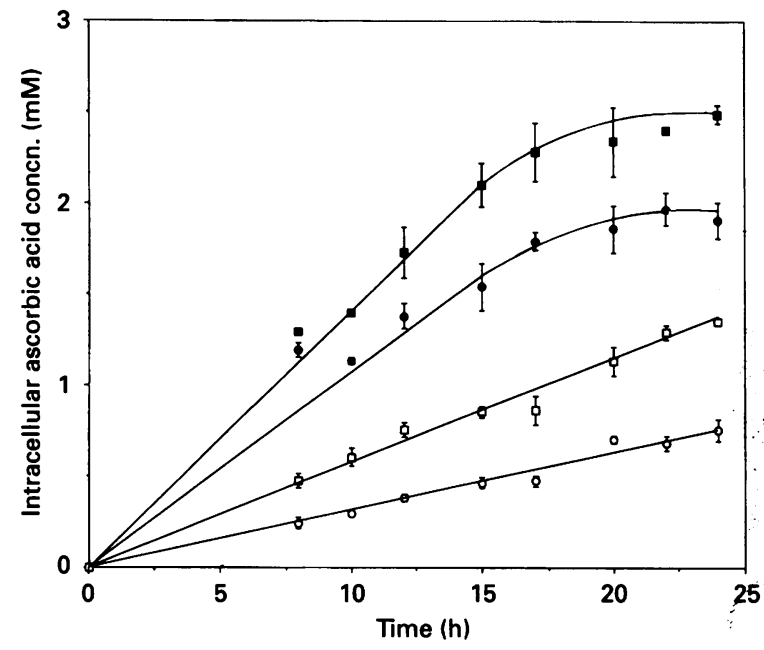

Figure 6 Uptake over time in the absence and presence of $\mathrm{Na}^{+}$

Fibroblasts were incubated in BSS with $500 \mu \mathrm{M}(\mathrm{O}, \bigcirc)$ and $1000 \mu \mathrm{M}(\square, \square)$ ascorbic acid with $(, \square)$ and without $(O, \square) \mathrm{Na}^{+}$over a $24 \mathrm{~h}$ period. The BSS was replaced every $8 \mathrm{~h}$ with BSS containing fresh ascorbic acid. At the indicated times, the cells were washed and harvested as described in the Materials and methods section.

fibroblasts and that the low-affinity component of ascorbic acid uptake is carrier-mediated. Intracellular binding of ascorbic acid could not account for these findings, since no binding of ascorbic acid to intracellular constituents was detected during subcellular-fractionation experiments (results not shown).

\section{Characterization of transport}

To test further whether the low-affinity activity was passive diffusion or carrier-mediated, we studied a variety of inhibitors 


\section{Table 1 Ascorbic acid transport and diffusion}

Fibroblasts were preincubated for $2 \mathrm{~h}$ with $3 \mathrm{mM}$ ascorbic acid in normal BSS. Controls were harvested $(t=0)$. BSS was then replaced with ascorbic acid-free BSS (without $\mathrm{Na}^{+}$) in the remaining wells, and the cells were allowed to incubate for $2 \mathrm{~h}$. At the end of this time, both the cell monolayer $(t=2 \mathrm{~h})$ and the buffer $(t=2 \mathrm{~h})$ were harvested. Ascorbic acid in both the cell monolayer (at $t=0$ and $2 \mathrm{~h}$ ) and the buffer (at $t=2 \mathrm{~h}$ ) was measured as described in the Materials and methods section. See the text for details.

\begin{tabular}{lc}
\hline Conditions & $\begin{array}{l}\text { Ascorbic acid } \\
\text { concn. (mM) }\end{array}$ \\
\hline Cell monolayer at $t=0$ & $0.85 \pm 0.05$ \\
Cell monolayer at $t=2 \mathrm{~h}$ & $0.80 \pm 0.04$ \\
Buffer at $t=2 \mathrm{~h}$ & $0.00053 \pm 0.00007$
\end{tabular}

\section{Table 2 Effects of inhibitors on ascorbic acid uptake}

Fibroblasts were preincubated for $15 \mathrm{~min}$ in BSS with the metabolic inhibitor indicated; $1 \mathrm{mM}$ ascorbic acid was then added to the cultures, which were allowed to incubate for $4 \mathrm{~h}$. Extraction was performed as described in the Materials and methods. Percentage ascorbic acid uptake is defined as $100 \times$ the mean of ascorbic acid uptake in the presence of inhibitor divided by the mean of ascorbic acid uptake in the absence of inhibitor $(n=3)$.

\begin{tabular}{|c|c|c|}
\hline Inhibitor & $\mathrm{Na}^{+}$ & $\begin{array}{l}\text { Ascorbic acid } \\
\text { uptake }(\%)\end{array}$ \\
\hline \multirow[t]{2}{*}{$100 \mu \mathrm{M}$ Cytochalasin $\mathrm{B}^{*}$} & + & 83 \\
\hline & - & 44 \\
\hline \multirow[t]{2}{*}{$100 \mu \mathrm{M}$ Phloretin* } & + & 10 \\
\hline & - & 33 \\
\hline \multirow[t]{2}{*}{$2 \mu \mathrm{M} \mathrm{FCCP*}$} & + & 31 \\
\hline & - & 31 \\
\hline \multirow[t]{2}{*}{$1000 \mu \mathrm{M} \mathrm{DNP}^{*}$} & + & 44 \\
\hline & - & 35 \\
\hline \multirow[t]{2}{*}{$10 \mathrm{mM} \mathrm{DCN}$} & + & 100 \\
\hline & - & 24 \\
\hline
\end{tabular}

* Cultures for both control and inhibitor contained ethanol (final concn. 1\% v/v).

for both transport activities. We predicted that if the low-affinity activity was carrier-mediated, it should be sensitive to metabolic inhibitors. The proton uncouplers DNP and FCCP were tested to determine if changes in $\Delta \mathrm{pH}$ or $\Delta \psi$ would inhibit ascorbic acid transport [22-24]. In addition, ascorbic acid transport in neutrophils is inhibited by glucose and glucose-transport inhibitors [25]. Cytochalasin B, phloretin and phlorizin are all inhibitors of glucose transport and of ascorbic acid transport in human neutrophils [25-28]. We predicted that these inhibitors could inhibit transport in fibroblasts. Finally, ascorbic acid uptake was analysed in the presence of $\mathrm{KCN}$ to test further for ATP-dependency by the ascorbic acid transporters. Ascorbic acid transport was measured in the absence and presence of $\mathrm{Na}^{+}$. Activity of the low-affinity transporter was determined in the absence of $\mathrm{Na}^{+}$. The $\mathrm{Na}^{+}$-independent low-affinity transporter was inhibited by cytochalasin B, phloretin, DNP, FCCP and $\mathrm{KCN}$ (Table 2). Uptake by the $\mathrm{Na}^{+}$-dependent high-affinity transport was determined by subtracting ascorbic acid uptake in the absence of $\mathrm{Na}^{+}$from that observed in its presence, yielding only $\mathrm{Na}^{+}$-dependent activity. The high-affinity transporter was inhibited by phloretin, FCCP and DNP, but only marginally by cytochalasin B (Table 2). Phlorizin had no effect on either

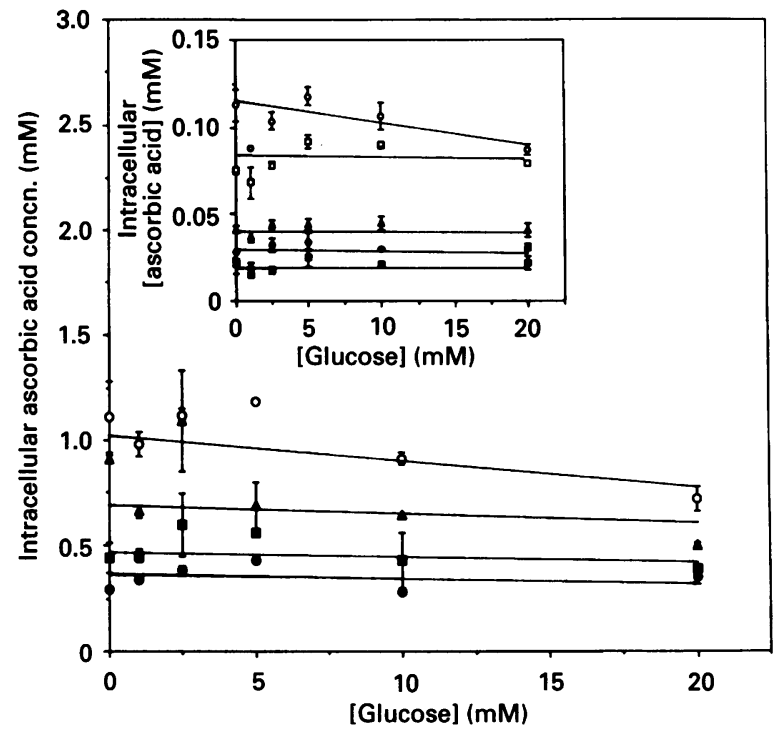

Figure 7 Glucose effects on ascorbic acid transport

Fibroblasts were incubated for $2 \mathrm{~h}$ in $0.3-5.0 \mathrm{mM}$ ascorbic acid; all other conditions were as described in the Materials and methods section, except for changes in the glucose concentration in the buffer. Ascorbic acid concentrations were: $0.3 \mathrm{mM}, \boldsymbol{O} ; 1.0 \mathrm{mM}, \boldsymbol{\square} ; 2.5 \mathrm{mM}, \boldsymbol{\Delta}$; $5.0 \mathrm{mM}, \mathrm{O}$. Inset: incubation for $2 \mathrm{~h}$ in $2-30 \mu \mathrm{M}$ ascorbic acid; all other conditions were as described in the Materials and methods section, except for changes in the glucose concentration in the buffer. Ascorbic acid concentrations were: $2 \mu \mathrm{M}, \boldsymbol{\square} ; 4 \mu \mathrm{M}, 0 ; 6 \mu \mathrm{M}, \boldsymbol{\Delta} ; 18 \mu \mathrm{M}$, $\square ; 30 \mu \mathrm{M}, O$. Samples were obtained and analysed as described in the Materials and methods section.

transporter (results not shown). These results demonstrate that ascorbic acid transport by both the high- and low-affinity activities is carrier-mediated uptake and not diffusion.

Cytochalasin B and phloretin inhibit glucose transport in fibroblasts [27,29]. Inhibition of the low-affinity ascorbic acid transporter by these compounds, as well as its $\mathrm{Na}^{+}$-independence, raised the possibility that the low-affinity transport was actually mediated by the glucose transporter. To exclude the possibility that ascorbic acid transport was facilitated transport via the glucose carrier, ascorbic acid transport was determined in the presence of varying concentrations of glucose. Ascorbic acid transport was not inhibited by external glucose concentrations up to $20 \mathrm{mM}$ (Figure 7), indicating that glucose and ascorbic acid are transported by separate transport systems.

Ascorbic acid uptake was tested for temperature-dependence at $37^{\circ}$ and $0{ }^{\circ} \mathrm{C}$. Ascorbic acid uptake by both the high- and the low-affinity transporters decreased over 10 -fold at $0^{\circ} \mathrm{C}$ (results not shown).

\section{DISCUSSION}

In this paper we demonstrate the uptake of ascorbic acid in human fibroblasts by two transport activities. The first component was a high-affinity active transport activity which had an apparent $K_{\mathrm{m}}$ of $6 \pm 2 \mu \mathrm{M}$ and an apparent $V_{\text {max. }}$ of $203 \pm 50 \mu \mathrm{M} / \mathrm{h}$. The activity was concentration- and temperature-dependent, saturable, $\mathrm{Na}^{+}$-dependent, inhibited by FCCP, DNP and phloretin, and generated ascorbic acid accumulation against a concentration gradient.

The second transport component was concentration-dependent, but was not saturable at ascorbic acid concentrations up to $10 \mathrm{mM}$. Attempts to increase the external ascorbic acid concentration above $10 \mathrm{mM}$ resulted in loss of cell adhesion and cell 
death. Kinetic analysis alone could not distinguish between passive diffusion and carrier-mediated uptake. Nevertheless, there is substantial evidence presented here that the second transport activity is active carrier-mediated transport. Ascorbic acid was transported against a concentration gradient by the low-affinity transporter in the absence of $\mathrm{Na}^{+}$(Figure 5). Diffusion of intracellular ascorbic acid to the outside was not observed under conditions of $0.8 \mathrm{mM}$ intracellular and zero extracellular ascorbic acid (Table 1), suggesting that the second uptake activity is not diffusion. These findings could not be accounted for by intracellular binding of ascorbic acid, as the vitamin was not bound. Ascorbic acid uptake by the low-affinity transport activity was inhibited by cytochalasin B, phloretin, DNP, FCCP and KCN (Table 2). To summarize, accumulation against a concentration gradient, inhibition of the low-affinity transporter by glucose transport and metabolic inhibitors, and the lack of diffusion from intra- to extra-cellular space, demonstrate that the low-affinity transport activity is carriermediated.

The results indicate that the driving force for the high-affinity transporter is the $\mathrm{Na}^{+}$gradient. Although the data indicate that the low-affinity activity is carrier-mediated active transport, the driving force is unknown. The data suggest that the low-affinity activity is not driven by either the $\mathrm{Na}^{+}$gradient or intracellular binding. High-affinity transport was inhibited by DNP and FCCP, but not by $\mathrm{KCN}$, whereas the low-affinity activity was inhibited by all three. The inhibition of the high-affinity transporter by the uncouplers may be due more to the alteration of $\Delta \psi$ rather than the decrease in available cellular energy. A more complete understanding of the mechanism of transport of the two ascorbic acid transporters awaits isolation of the two different activities.

Ascorbic acid transport in human neutrophils is mediated by a two-component transport system which shares several features with ascorbic acid transport in fibroblasts. Transport in both cell types is mediated by two active components, is temperaturesensitive, and is inhibited by phloretin. The high-affinity transport activities have similar kinetic constants, are $\mathrm{Na}^{+}$-dependent, and are inhibited by FCCP. However, cytochalasin B is an effective inhibitor of high-affinity activity in neutrophils, but is substantially less effective in blocking high-affinity transport in fibroblasts. The low-affinity activities in neutrophils and fibroblasts have a similar $K_{\mathrm{m}}$, but the $V_{\text {max. }}$ is 15 -fold greater in neutrophils. In contrast with fibroblasts, the low-affinity activity in neutrophils is $\mathrm{Na}^{+}$-dependent and is inhibited by glucose ([14,25]; Y. Wong, P. Washko and M. Levine, unpublished work). Reasons for the differences between the two transporters will have to await the isolation of the transport proteins, as above.
Ascorbic acid accumulation by human fibroblasts is a beginning step in applying the principles of 'in situ kinetics' to collagen biosynthesis. The goal of in situ kinetics is to learn quantitatively how different concentrations of vitamin, in this case ascorbic acid, regulate a biochemical process in situ. The data in this paper provide the first step for studies of in situ kinetics of ascorbic acid in human fibroblasts by quantifying intracellular ascorbic acid as a function of extracellular concentration. The next steps in examining the role of ascorbic acid in collagen biosynthesis, the relationship between ascorbic acid concentration and proline hydroxylation, are in progress.

\section{REFERENCES}

1 Robertson, W. Van B. and Schwartz, B. (1953) J. Biol. Chem. 201, 689-696

2 Blanche, T. J. J. and Peterkofsky, B. (1975) Arch. Biochem. Biophys. 171, 259-267

3 Peterkofsky, B. and Udenfriend, S. (1965) Proc. Natl. Acad. Sci. U.S.A. 53, 335-342

4 Hutton, J. J., Tapel, A. L. and Udenfriend, S. (1967) Arch. Biochem. Biophys. 118, 231-240

5 Berg, R. A. and Prockop, D. J. (1973) J. Biol. Chem. 248, 1175-1182

6 Risteli, J., Tryggvason, K. and Kivirikko, K. I. (1977) Eur. J. Biochem. 73, 485-492

7 Rhoades, R. E. and Udenfriend, S. (1968) Proc. Natl. Acad. Sci. U.S.A. 60 1473-1478

8 Edwards, L. C. and Dunphy, J. E. (1958) N. Engl. J. Med. 259, 275-285

9 Levine, M. (1986) N. Engl. J. Med. 314, 892-902

10 Committee on Dietary Allowances, Food and Nutrition Board (1980) Recommended Dietary Allowances, 9th edn., pp. 72-81, National Academy of Sciences, Washington DC

11 Levine, M. (1989) Nutrition (Burbank, CA) 5, 428

12 Levine, M. (1986) J. Biol. Chem. 261, 7347-7356

13 Dhariwal, K. R., Washko, P., Hartzell, W. O. and Levine, M. (1989) J. Biol. Chem. 264, 15404-15409

14 Washko, P., Rotrosen, D. and Levine, M. (1989) J. Biol. Chem. 264, 18996-19002

15 Dhariwal, K., Shirvan, M. and Levine, M. (1991) J. Biol. Chem. 266, 5384-5387

16 Washko, P., Hartzell, W. O. and Levine, M. (1989) Anal. Biochem. 181, 276-282

17 Smith, P. K., Krohn, R. I., Hermanson, G. T., Mallia, A. K., Gartner, F. H., Provenzano, M. D., Fujimoto, E. K., Goeke, N. M., Otson, B. J. and Klenk, D. K. (1985) Anal. Biochem. 150, 76-85

18 Bergsten, P., Amitai, G., Kehrl, J., Dhariwal, K., Klein, H. and Levine, M. (1990) J. Biol. Chem. 265, 2584-2587

19 Neame, K. D. and Richards, T. G. (1972) Elementary Kinetics of Membrane Carrier Transport, pp. 16-55, Wiley, New York

20 Diliberto, E. J., Jr., Heckman, G. D. and Daniels, A. J. (1983) J. Biol. Chem. 258 12886-12894

21 Padh, H. and Aleo, J. J. (1987) Biochim. Biophys. Acta 901, 283-290

22 Slater, E. C. (1950) Biochem. J. 46, 484-499

23 Slater, E. C. (1967) Methods Biochem. 10, 48-57

24 Heytler, P. G. (1979) Methods Biochem. 55, 462-472

25 Washko, P. and Levine, M. (1992) J. Biol. Chem. 267, 23568-23574

26 Chen, S. R. and Lo, T. C. Y. (1988) Biochem. J. 251, 63-72

27 Kono, T. (1988) Vitam. Horm. (N.Y.) 44, 103-154

28 D'Amore, T. and Lo, T. C. Y. (1986) J. Cell. Physiol. 127, 95-105

29 Kletzen, R. F., Perdue, J. F. and Springer, A. (1972) J. Biol. Chem. 247 2964-2966 